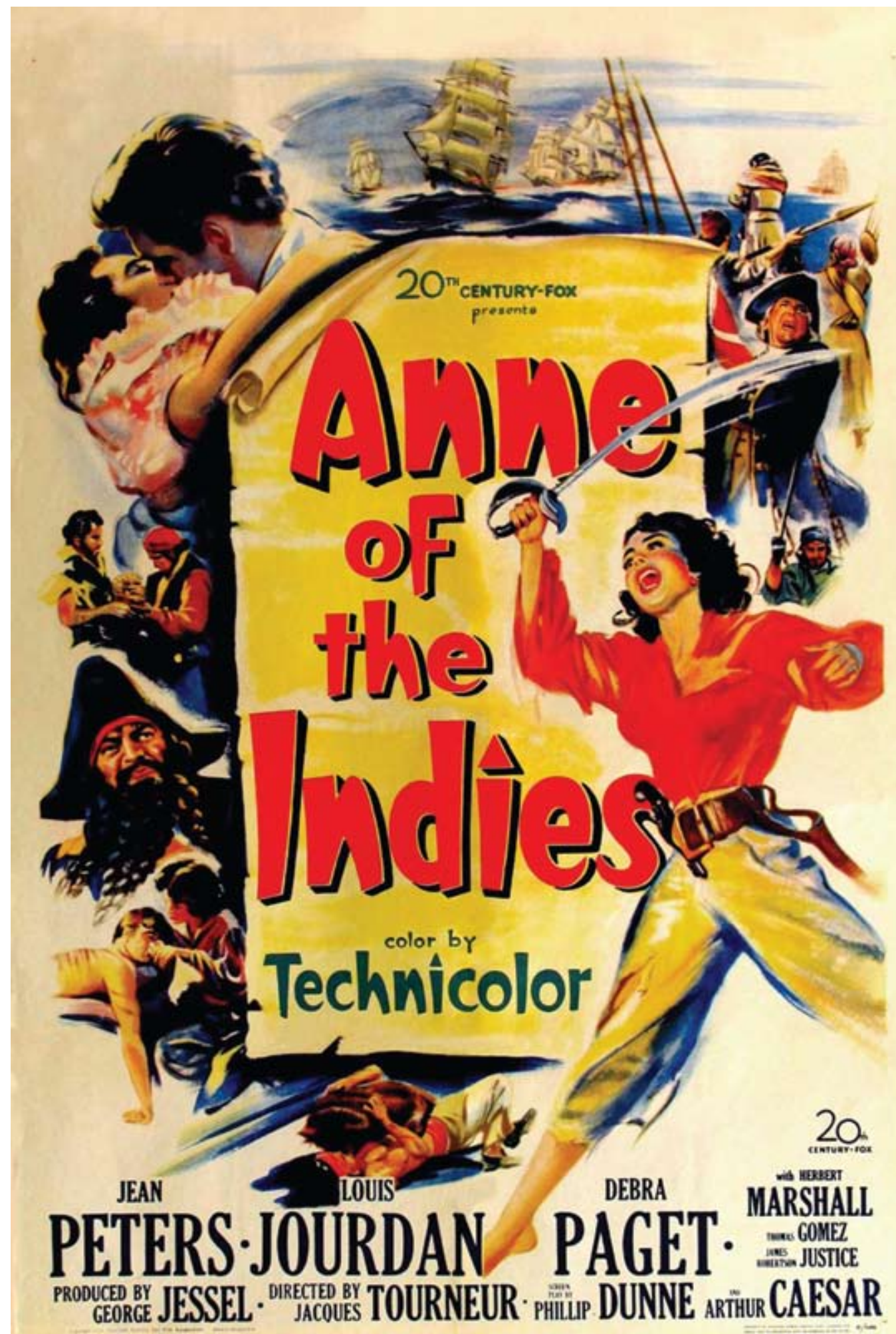




\section{Notes Toward a History of the Edinburgh International Film Festival, 1969-77}

\section{By Peter Stanfield}

\section{Keywords: Edinburgh \\ International Film Festival (EIFF), film theory, film studies, auteurism, Lynda Miles, Peter Wollen, Claire Johnston, Paul Willemen}

Looking back over developments in British film culture since the late 1960s, one of the principal organizers of the Edinburgh International Film Festival (EIFF), David Will, wrote that the Festival 'arrived as an institution of oppositional culture in 1969' (Will 1982: 20). During the 1970s the EIFF radically challenged the accepted idea of a film festival as a showcase for new releases and a benign cultural event designed to foster tourism and investment. Against the grain, the Festival gave a platform to film theory, experimental film, new European and world cinema, maverick film-makers and American exploitation movies. The paradox of an established organization working as an instrument of resistance towards the dominant culture underscores the history of the EIFF during the 1970s, when the Festival became notorious for its provocations and interventions into film culture. No other film festival has set the agenda for the way that films might be viewed and understood as happened at Edinburgh between the Samuel Fuller retrospective in 1969 and the History/ Production/Memory event in 1977. Uniquely among film festivals, the EIFF maintained not only a dialogue with film theory, but was also a primary platform for its dissemination.

Over the course of eight years the Festival ran the first career retrospectives, not only

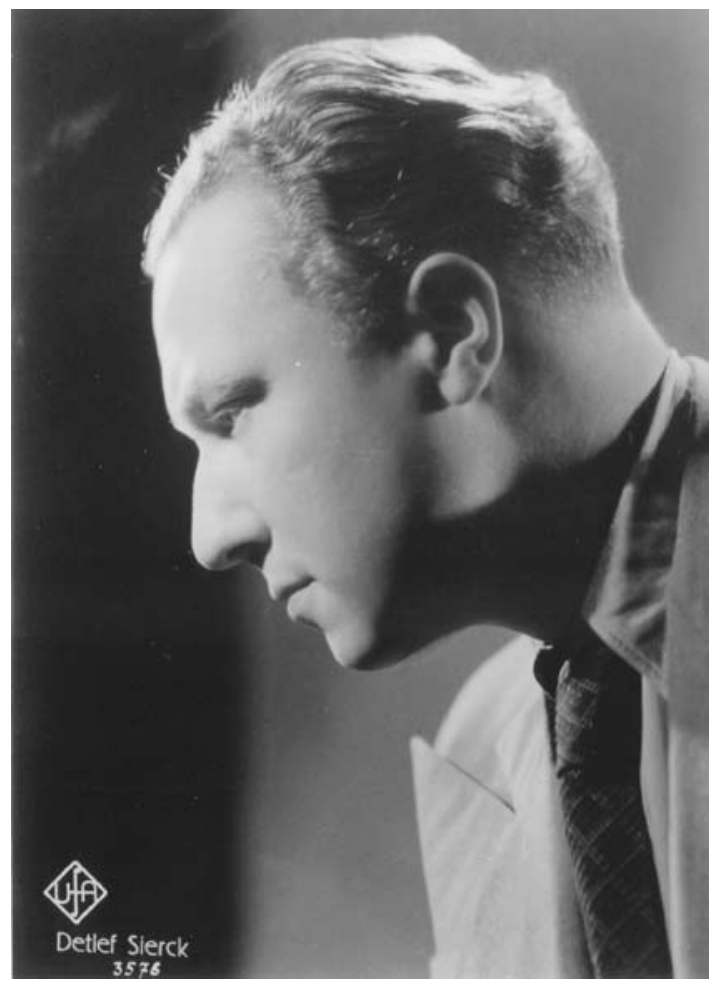

'During the 1970s the EIFF radically challenged the accepted idea of a film festival as a showcase for new releases and a benign cultural event designed to foster tourism and investment.'

of Fuller but also of Roger Corman, Douglas Sirk, Frank Tashlin, Raoul Walsh and Jacques Tourneur. Fuller, Corman and Sirk attended the Festival and helped to establish its reputa- 
tion as an event that wholly encouraged the attendance and participation of film-makers, both new and old. It presented the first European women's film event, and was the first international film festival to be run by a woman, it took the lead not only in gender politics, but also Marxism and film through events such as that built around Brecht and the cinema, and, alongside the film studies journal Screen, it broke new ground in its work on psychoanalysis and film. Beyond these achievements in film theory, the Festival presented cutting edge programming that gave screen space to an extraordinary mix of low-budget American movies, avant-garde cinema and a formidable range of non-Englishlanguage films. EIFF also published a series of seminal auteur studies and two issues of a magazine dedicated to vanguard film criticism. Its intellectual legacy is crucial to any properly formulated history of film studies in Britain, and its eclectic programming better exemplified the vibrant and experimental nature of international film culture during the 1970s than any other film festival of its time.

\section{The young idea}

Beginning in 1947, the EIFF's remit was to show the best of international cinema, with the guiding spirit of John Grierson as a heavy influence on early programmes. Emphasizing Italian neo-realist dramas and documentaries from around the world, Hollywood products were notably absent from the Festival's early line-ups. By the mid to late 1960s the Festival had become a dull affair, little more than a showcase for films chosen by government and industry agents, alongside films that had an often tenuous connection to Scotland, and British movies that carried the hallmark of respectability. In 1968 a young film-maker, Murray Grigor was assigned the job of director. He helped to instigate a more proactive programming policy, with the Festival organizers now selecting the films. Hollywood products were given a showcase, though invariably these were from the independent studios, particularly AIP. The Festival was not, nor would it become, a shop window for the latest American extravaganzas. The film critic for the London Times, John Russell Taylor, wrote approvingly of the changes:
Last year the Edinburgh Film Festival was radically remade: out with drably conservative features and solid documentary, in with Roger Corman, international underground and the young idea. The idea was not only young, but good. By choosing to lay the festival's main accent on specialist weeks devoted to a particular country or school and on retrospectives of the sort of film-maker rarely so honoured over here, the organizers immediately gave it a new twist, and removed it from the regular rat race, in which too many festivals chase too few films of any real merit. (Taylor 1969)

The 'young idea' was driven by Grigor's recruitment of two cinephiles and Edinburgh University undergraduates Lynda Myles and David Will. They were responsible for running the university's film society and had come to Grigor's attention when they wrote an angry letter to the Scotsman denouncing the Festival's conservative programming. What Will and Myles brought to the Festival was a knowledge of French film theory gleaned from the pages of Cahiers du Cinema and Positif and an enthusiasm for cultist American cinema, particularly that produced by maverick film directors such as Samuel Fuller. In order to help galvanize this interest they contacted Peter Wollen who had been writing about American auteurs for the New Left Review since the early 1960s, and was now a leading figure in London's film culture as it was formed around the British Film Institute's educational department and the Society for Education in Film \& Television, which published Screen.

\section{Cinephilia and Samuel Fuller}

With Peter Wollen in tow, Myles and Will inaugurated a series of film retrospectives, educational events and publishing ventures that were groundbreaking as film festival attractions, but were also highly influential on the emerging discipline of film studies. The initial event organized by these young lovers of film was the programming of the Samuel Fuller retrospective. Along with the critics at Movie, Wollen had taken the lead in Britain in writing about Fuller (Russell [Wollen] 1964). His championing of the director 
was as much an act of provocation aimed at the critical establishment as it was an attempt to move film criticism away from a posture that depended upon received notions of good taste and the well-made film.

In the same spirit of revolt, the EIFF organizers introduced Fuller to festival-goers with an aggressive verve:

This retrospective is designed to give the first fully comprehensive showing of his works in Britain, and is intended to demonstrate unequivocally that Fuller is one of the major film directors to have emerged from America since the war. There is no need to substantiate this claim. Fuller's vindication lies in his films, which are obligatory viewing for anyone who claims to have an interest in the cinema. (EIFF programme 1969: 36)

The organizers were putting on a show of bravado, the unequivocal claim that Fuller was an important film director and his films were obligatory viewing was made in the face of what they knew would be disbelief on the part of the old guard of festival patrons and cynical film fans.

The high valuation given to Fuller's films by the organizers was as heartfelt as it was provocative. The imprimatur placed on him by being showcased at such a prestigious event had the effect of drawing a heavily demarcated line in the sand. As of 1968-69 the Festival was no longer a purveyor of middlebrow film fare; from then onwards it would assume an innovative, oppositional face, offering a platform for cultish directors and a window for some of the most exciting developments in international filmmaking. In a profile of the Festival's director, the Scotsman wrote about the loss of direction and momentum in the mid-1950s when the show was taken over by administrators who had little enthusiasm for film:

The tacky intraversion [sic] threw Edinburgh into a polite and middle-brow Festival, neither earnest or enthusiastic. It was the time when one Festival director, baring out to Turnhouse to meet and honour some Swedish starlet, passed Visconti going the other way. Only Visconti wasn't there for the film he was there for the opera. (Scotsman 1970) ${ }^{1}$

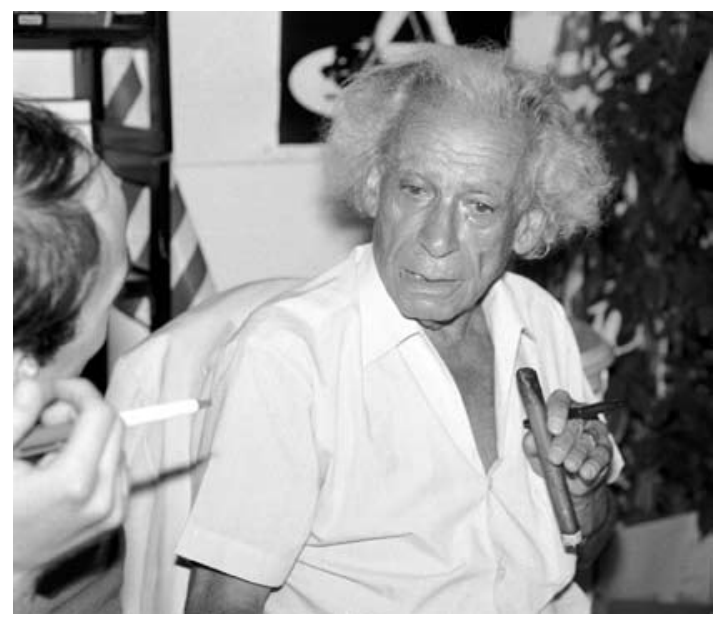

'By the mid to late 1960 s the Festival had become a dull affair, little more than a showcase for films chosen by government and industry agents...'

The key difficulty facing Grigor, Myles and Will in their attempt to bring the Festival back to life was the competing shows in Venice, Berlin and Cannes. These were more prestigious, better funded and had first choice of the new releases. The EIFF was run on a shoestring with grants from the Scottish Film Council and Edinburgh Corporation, it had no industry sponsorship and, unlike its main European rivals, films were not shown in competition. The organizers' response was, according to the Scotsman, to make the Festival's remit 'wider and wilder':

Last year it was. The underground was here; student movies were shown; the first major retrospective on Samuel Fuller, the amazing American movie-maker, was mounted and duly transferred to London; there was youthemphasis which sometimes seemed uncritical but almost never seemed dull. (Scotsman 1970)

Because of the small grants given to support the Festival, box office returns were the most important revenue stream. The Festival, then, had no choice but to break with past programming: "We can't ask the public to see water 
purification movies," Grigor said, "or at least, not many of them."' (Scotsman 1970) Programming would be modelled on Henri Langlois's philosophy at the Paris Cinémathéque: 'cinemas as bookshops where you can pick up what you want', with Will and Myles making a number of trips to Paris to consult with Langlois and his colleagues on programming as well as to borrow prints of films otherwise unavailable in Britain (Scotsman 1970). ${ }^{2}$

\section{The Corman connection}

The Festival maintained its international dimension; in 1970, films from eastern and western Europe were shown alongside examples of Brazilian cinema and new mid-budget American releases such as Coppola's Rain People and Bob Rafelson's Five Easy Pieces. Gala performances were given for Susannah York's latest starring vehicle, Country Dance, and her appearance at the Festival drew headlines in the Scottish press. A major retrospective was devoted to the films of Claude Chabrol; there was also an appearance by Hollywood executive Darryl Zanuck, and a celebration of his work through 'cameo' screenings of some of the films he produced for Fritz Lang and John Ford.

At the cult end of the spectrum there was also the first retrospective of the work of Monte Hellman, who had yet to make TwoLane Blacktop, and since the westerns Ride the Whirlwind and The Shooting, both made in 1966, had not directed a feature film for four years. His three earlier films, Beast from the Haunted Cave (1959), Back Door to Hell (1965) and Flight to Fury (1965) were all made under the aegis of producer Roger Corman. The programme notes reveal that Hellman acknowledged an influence in Italian neo-realism, and he 'employs very self-conscious camera style and montage, with the result that his films often appear schematic' (EIFF programme 1970: 61). While this gives a rather high-brow response to the pulp exploitation material that was the main rationale behind the Corman productions, it was the westerns that were of real interest to the programmers: 'His Westerns have met with little approval in the States, where the nihilism and despair that they express questions the basis of American ideology, and undermines the fundamental elements of the Western

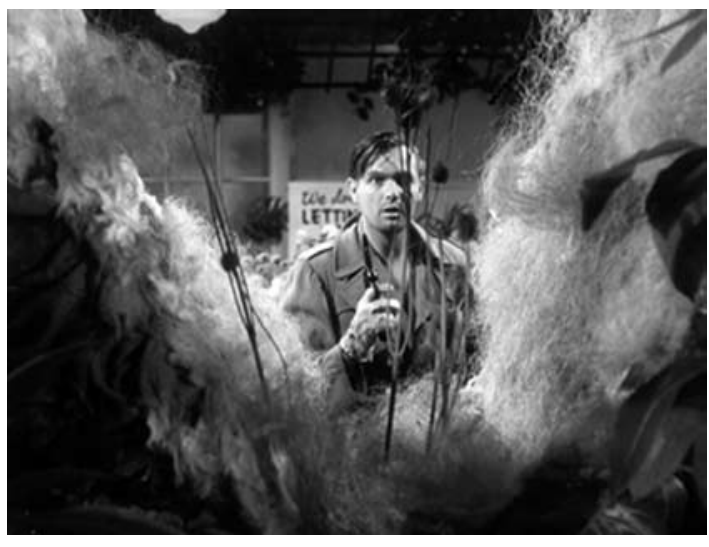

'The key difficulty facing Grigor, Myles and Will in their attempt to bring the Festival back to life was the competing shows in Venice, Berlin and Cannes. These were more prestigious, better funded and had first choice of the new releases.'

as a genre.' Coupled with the embracing of American movies that had been rejected by their indigenous reviewers was the perceived subversive potential of B-movies to undermine their own formulaic concerns. This intellectual overlaying of formal and ideological concerns, rather self-evidently, was of little if any concern to the producers of B-movies, nor, least of all, to their intended audience. These were approaches to American cinema that were already circulating internationally in the wider world of film culture, but EIFF gave to the interest in subversive cinema a legitimate platform and in doing so it amplified and further disseminated the critical practice engaged with the study of popular culture. These were the high years of cinephilia: 'We caught the movie buff explosion, in the mid-sixties, and we were on the right wavelength', Grigor said in 1970 (Scotsman 1970). The 1960s cinephilia was not just a passing affair; it was, Myles was later to reflect, 'as important as breathing'. ${ }^{3}$ This ardour is still keenly felt in the festival documents, publications and press releases of the period. 
The Hellman retrospective was linked to a gala screening of Roger Corman's Bloody Mama and Gas! -Or- It Became Necessary to Destroy the World in Order to Save It, which in turn were links back to the previous year's 'History of A.I.P. Thru Roger Corman'; a retrospective that was inspired by the gala screening in 1968 of AIP's Wild in the Streets. Given the cultural current of cinephilia, and the championing of illegitimate strands of American film-making, whether it was the New York underground (Andy Warhol and Kenneth Anger both had screenings of their films at the 1969 EIFF) or exploitation specialists like AIP and Corman, the programming made sound political and economic sense. Like Corman with his low-budget grind-house movies and the American underground with its iconoclastic shock tactics, the EIFF, with its shoestring funding, had to do whatever it could to grab the headlines and encourage patronage. The link with Corman would continue over the next few years; the Festival also showed particular loyalty to the early work of Jonathan Demme, screening The Hot Box (1972), Caged Heat (1974) and Crazy Mama (1975). The programme noted that, working 'within the limits of the softcore exploitation movie, Demme has sought to subvert the traditional conservative values of the genre to examine the nature of revolution, and the limits of revolution through action' (EIFF programme 1975: 78). The EIFF sought to have the same seditious effect on the reactionary philosophy that underpinned traditional film festival programming as Demme, Hellman, Corman, Sirk or Fuller were said to have had on film-making.

\section{Promoting film theory}

The intellectual justification for showing exploitation material, however, held little sway with some segments of the local community. The provocative nature of the programming backfired in 1970 when the Festival found itself out of favour with the bailies, local magistrates who were responsible for passing films as suitable for public screening. These custodians of public morals took offence at both the violence of Bloody Mama and the explicit sexual activities shown in Jorn Donner's quasipornographic Portraits of Woman. The former was cleared for one screening only, the latter was shown only to the press. But if the bailies

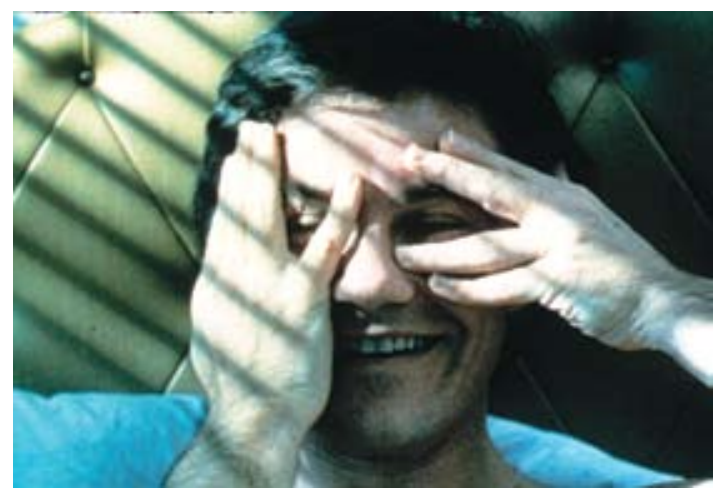

'Programming would be modelled on Henri Langlois's philosophy at the Paris Cinémathéque: "cinemas as bookshops where you can pick up what you want..."'

made life difficult for the Festival organizers, their reactionary view of film culture helped ensure the Festival's growing reputation as provocative, cutting edge and youth oriented.

The Festival was also intellectually robust. Uniquely, each year between 1969 and 1976 it published collections of scholarly articles which, initially, underpinned a particular retrospective, beginning with Samuel Fuller, followed by Roger Corman, Douglas Sirk, Frank Tashlin, Raoul Walsh and Jacques Tourneur. In each case, they were the first books published in English on these auteurs, and it is their continued circulation that gives the 1970s EIFF the highly esteemed profile it still enjoys today. The books document the intellectual debates on film that held sway in Britain during this short but intense period. Their symbolic value in the cultural wars fought around film in this period was brought to the fore when, in a fit of pique encouraged by the gnostic ruminations found in the Walsh volume, the public face of film culture in 1970s Britain, Barry Norman, ripped up a copy on the BBC's flagship film review programme.

In 1972 Lynda Myles, Laura Mulvey and Claire Johnston programmed a season of films dedicated to the work of women directors 
that was truly groundbreaking. The first of its kind in Europe, it included films from various decades, nations and genres: from early suffragette documentaries to Barbara Loden's Wanda (1970), via Leontine Sagan, Leni Riefenstahl, Dorothy Arzner, Ida Lupino and many others. The event included talks by film-makers and a symposium; it also prepared an edition of the $B B C$ arts programme Late Night Line-up, the content of which was produced by a cooperative of women film-makers. Though taken up in the press coverage as yet another novel EIFF programming event, the season was also an indicator of the shifting political terrain of film culture in the early 1970s. Sirk's melodramas had their first retrospective during the same 1972 Festival which was programmed with the help of Mulvey and Jon Halliday, and this allied with the women's event indicated a move away from the marked masculine address of Fuller's action films and Corman's exploitation cinema, and a shift toward films addressed to a female audience and the politics of representation. The emphasis on world cinema and cultist auteurist programming would continue to be a mainstay of the Festival: retrospectives of Frank Tashlin and Irwin Kershner in 1973, for example, played alongside the African cinema of Ousmane Sembene, the New German Cinema of Werner Herzog and Rudolf and Karen Thome, a season of Japanese independents, and the experimental film works sponsored by The Other Cinema. Yet the women's event inaugurated a more thorough engagement on the part of the Festival's organizers with the politics and practices of film-making.

\section{A new director}

In 1973, Lynda Myles took over the Festival's directorship from Murray Grigor, who had stepped down in order to concentrate on film-making. She would continue in the post as director through to 1980 , overseeing some of the most successful Festival programmes while maintaining a giddy dialogue between mainstream film culture and cutting edge film theory. From the outset, Myles strove to be inclusive in her programming decisions, and to maintain a good flow of receipts at the box office. This was achieved partly through making a dual audience appeal in the marketing pitches given to the press. While the fact that a woman ran the Festival and that the majority of the organizers were women was celebrated, there was also an insistence that this was not the decisive factor in making programming decisions. An article on Myles and the Festival in the Sunday Times began by noting that the previous year's women's event had transferred to the National Film Theatre in London. The newspaper reported:

It was an affair of dialectic, almost violent at times. 'It had to be done', Lynda says, since she was one of its main architects. 'Women simply aren't taken seriously in the film business. But it was a once-and-for-all thing as far as I'm concerned. I'd love to show lots of good films by women, but they have to be good films. I really don't feel like devoting my life to the feminist cause.'

\section{So far, only one of Edinburgh's films this} year was directed by a woman. (Pye 1973)

Myles, then, both promoted and downplayed feminism, just as she advanced film theory while ensuring that the programmes still entertained. ${ }^{4}$

Discussing the Tashlin retrospective she thought it ridiculous that film festivals bother so little about Hollywood, the source of much of the best in film making. I don't see why people shouldn't enjoy films at all sorts of levels. Some people, for instance, will just get a good laugh from the Jerry Lewis ones we are showing, while others are busy appreciating the very astute commentary the director was making on American middle-class life and values. (Scotsman 1973)

The dual appeal here is echoed elsewhere in the programming, so that, for example, Tarkovsky's Andrei Rublev was balanced with the latest Hammer horror - Frankenstein and the Monster from Hell.

By 1974 the battle lines in British film culture had become so entrenched that in an interview Myles was asked where she located herself in the 'spectrum of British Film Culture from the BFI/Sight and Sound position to the Screen group?' her diplomatic response suggested she was surfing just ahead of the schisms that were opening up behind her: 
My cinematic education started with Sarris and Cahiers and of course Movie had a seminal influence so to that extent we have always been apart from the establishment position. We began to feel last year that we must go beyond the auteur theory. I am an associate editor of Screen and involved with the critics on Screen and this is why Walsh will be the last of the big American retrospectives. Next year we had an idea that it might be interesting to do something like Brecht in the cinema. (Festival Times 1974)

Though the break with auteurism would not come until 1976, following the Tourneur retrospective, the progress of film theory as outlined in the EIFF booklets had developed exponentially since the publication of the Fuller volume. Working alongside Myles and Will, Wollen had been a key player in the Fuller retrospective and in the programming of avant-garde films, particularly the landmark 1976 programme, but his participation diminished as he, with Mulvey, became more involved in film-making. Alongside Will, their role, in all but name, had been to act as the Festival's intellectuals; gradually, however, their unofficial advisory position was assumed by Claire Johnston and Paul Willemen. Will, Myles, Wollen, Mulvey, Johnston and Willemen were all formidable scholars: young, enthusiastic, political and absolutely dedicated to the task of establishing a rigorous critical platform upon which film could be engaged with seriously and in a manner and language that recognized it as the most important art form of the twentieth century. In their introduction to the Tourneur volume, editors Johnston and Willemen wrote:

Elaborating on the new policy initiated by last year's Edinburgh Film Festival book on Raoul Walsh, edited by Phil Hardy, the Tourneur Retrospective emphasizes the shift away from traditional auteurist retrospectives towards a foregrounding of the problem of reading and text construction. The retrospective does not propose a new author to be discovered, but a series of texts the reading of which will hopefully contribute to the clarification or formulation of important critical/theoretical issues in relation to the wider question of the development of a film culture. (Johnston and Willemen 1975: 6)

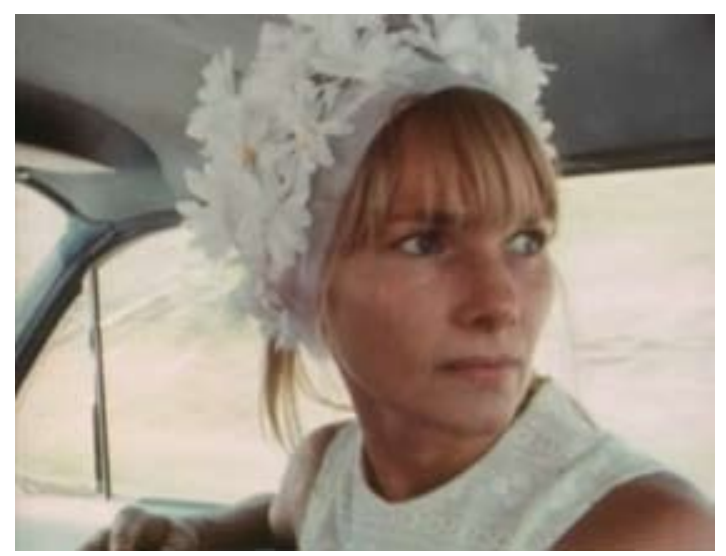

The editors went to some lengths to explain that their theoretical position vis-à-vis popular cinema was in line with avant-garde textual practices:

Far from the critique of classic Hollywood cinema being made at the expense of focusing on political or avant-garde cinema, we see the analysis of text construction, representation and other such processes inaugurated by these new concepts, as being the only possible foundation for any aestheticopolitical vanguard film-making in Britain today. (Johnston and Willemen 1975: 6)

'Notes Towards the Construction of Readings of Tourneur' was the title of Willemen's essay, wherein Tourneur the director had become 'Tourneur', a concept that was to be 'used as a formula to designate a particular activity of reading/writing'. Over the course of the essay Willemen plots his way across the 'formula' pulling in Roland Barthes, Jean Louis Baudry, Jacques Derrida, Jacques Lacan, Julia Kristeva and Christian Metz to help him extend his reading of the contradictions that undermine an 'apparent ideological coherence and invite the reader to distrust the phenomenal surface of the imageband, proposing themselves as texts to be read rather than to be absorbed or experienced' (Johnston and Willemen 1975: 17). In other words, the object of study - classical Hollywood cinema - had not changed, nor had the perception that there was something vaguely subversive, or maybe even seditious, in films produced by certain directors if a critic had the wherewithal to discover it. What had changed, however, was the panoply of theoretical armature now amassed 
for the benefit of the film critic and his/her readers. Though the speed with which Willemen can introduce a concept and then put it to work before dropping it to introduce a further concept can be a frustrating experience, to say the least, and demands an extraordinary leap of faith on the part of a reader unfamiliar with the theoretical context he or she has been thrown into, the gusto with which he approaches his task and the sense of excitement he conveys as he breaks new ground cannot be denied. One senses film criticism reinventing itself as film studies.

However, where the sense of the new idea of film studies is most keenly felt is in the writings of Johnston. Her essay on the gender masquerades of Anne of the Indies is an extraordinary achievement. Alongside Pam Cook's and Johnston's 'The Place of Women in the Films of Raoul Walsh', published in the previous festival booklet, the women's event and Myles's appointment as festival director, Johnston's essay pointed the way to the future of film studies and a newly articulated relationship with American cinema which highlighted film's ideological processes, particularly those that related to the politics of representation.

In 1976 and 1977 the auteur-focused booklet was dropped in favour of a more eclectic coverage. The 1976 issue considered Psycho-Analysis/ Cinema/Avant-Garde, and the 1977 issue considered History/Production/Memory. In eight years the contributors to the Festival's publications had moved from 'studies of the work of individual directors, exploring the structural configurations providing the coherence of a given director's work' (EIFF 1976: 3) to seeing their 'primary task as intervening in the politics of British film culture through the examination of film not as a pre-determined object for consumption but as a practice, an ideological practice' (EIFF 1977: 5).

Outside of the booklets published by the Festival the most obvious manifestation of this new line articulated by Johnston and Willemen was the series of screenings under the banner 'Brecht and the Cinema/Film and Politics', that ran parallel to the Tourneur season in 1975. Mindful of the box office, Myles continued the mix of international feature films, experimental cinema and cultist American movie fare. The year 1975 also produced the first British retrospective of Martin Scorsese's work, from his early shorts through to Alice Doesn't Live Here Anymore (1974). The retrospective continued the Festival's now long- running programming of films produced by Corman, or directed by one of his protégés (Scorsese had directed Boxcar Bertha for the producer in 1972), but it also continued and emphasized the Festival's support for the New American Cinema of Rafelson, Hellman, Coppola and such like. ${ }^{5}$ These were film directors who saw themselves as working outside the studio system and who aligned themselves explicitly with the older generation of maverick American film-makers like Fuller. In the programme notes for the Scorsese retrospective the director is quoted:

I am crazy about Samuel Fuller! I have only met him once, but we talked for a long time about emotional violence, which one mustn't confuse with physical violence. Fuller's films taught me that, and also that this emotional violence must not only be created by the actor but above all by the camera. (EIFF programme 1975: 6)

\section{Conclusion}

In the years preceding the Scorsese retrospective the Festival had worked hard and enthusiastically to give a platform to the kind of film-makers with whom someone like Scorsese could claim allegiance. The Festival's programming of cultist auteurs gave credence to Scorsese's support of a film-maker whose work prior to 1969 had received marginal acceptance and recognition from only a small coterie of film critics. The same was true of Corman and Sirk. Beyond offering a platform for the rescuing of forgotten or ignored American directors, the Festival's programming of non-English-language films was also remarkably innovative, pulling in films from all four corners of the globe. Neither did it lose faith with experimental cinema during the period under review, offering unique historical retrospectives alongside first views of cutting edge film-making that sat well against the avant-garde film theory upon which the Festival is now best remembered. The 1960s and 1970s were the high point of international film culture, and the EIFF played a vital part in broadening and deepening our understanding of film's potential. A film history of the period that did not engage with the Festival's programming, events, publications and provocations would indeed be an impoverished history. 


\section{Addendum}

Since retiring as director of the EIFF in 1980, Lynda Myles has worked in film and television production and consultancy, and is now Head of Fiction Direction at the National Film \& Television School in the United Kingdom. Murray Grigor has maintained his career as a writer and director of films on art, architecture and cultural politics. After making experimental films in the 1970s, Laura Mulvey and Peter Wollen pursued careers as film scholars. Wollen has since retired and Mulvey is presently a professor at Birkbeck College, University of London. Paul Willemen and Claire Johnston also pursued careers in film scholarship. Johnston died in 1987 and Willemen is currently a professor at the University of Ulster. After his time with the festival David Will no longer had an active involvement in film culture. The festival continues on to this day and now runs during the month of June.

\section{Acknowledgements}

I would like to offer a special thank you to Lynda Myles for taking the time and trouble to discuss with me the history of the EIFF. Acknowledgement also must go to Esther Sonnet and Dina lordanova for their editorial interventions and to Laura Mulvey for putting me straight on her part in this history. •

\section{Contributor details}

Peter Stanfield is Reader in Film Studies at the University of Kent and author of Body \& Soul: Jazz \& Blues in American Film, 1927-63 (2005), Horse Opera: The Strange History of the Singing Cowboy (2002), Hollywood, Westerns and the 1930s: The Lost Trail (2001), joint editor of Mob Culture: Hidden Histories of the American Gangster Film (2005) and 'Un-American' Hollywood: Politics and Film in the Blacklist Era (2008).

\section{References}

Edinburgh International Film Festival (EIFF) programme (1969).

Edinburgh International Film Festival (EIFF) programme (1970).

Edinburgh International Film Festival (EIFF) programme (1975).
Edinburgh '76 Magazine (EIFF) (1976), p. 3.

Edinburgh '77 Magazine (EIFF) (1977), p. 5.

Festival Times (1974), 'Lynda', reproduced in the EIFF press dossier.

Johnston, Claire and Willemen, Paul (1975), Jacques Tourneur, Edinburgh Film Festival.

Pye, Michael (1973), 'Lowland Fling', Sunday Times, reproduced in the EIFF press dossier.

Russell, Lee [Peter Wollen] (1964), 'Samuel Fuller', New Left Review, 1: 23 (JanuaryFebruary), pp. 86-89.

Scotsman, The (1970), 'The Man Who Brought the Film Festival Back to Life', reproduced in the EIFF press dossier, unpaginated.

Scotsman, The (1973), 'Lynda Myles from Critic to Director', reproduced in the EIFF press dossier.

Taylor, John Russell (1969), 'Edinburgh Goes Pop', The Times, 23 August.

Will, David (1982), 'Classic American Cinema: Sam Fuller', Framework, 19, p.20 .

Willemen, Paul (1982), 'Edinburgh Debate', Framework, 19, pp. 48-52.

\section{Endnotes}

1 Copies of the press dossiers for each year of the Festival are held by the British Film Institute library.

\section{Lynda Myles discussed the Paris \\ trips with me in an interview con- ducted in London, 25 September 2007.}

3 Interview with Myles, 25 September 2007.

4 Paul Willemen noted the difficulties

Myles encountered and her success in managing both the 'reactionary' and 'progressive' elements involved in the financing and running of the Festival in his introduction to the Joseph H. Lewis season, that ran at the Festival in 1980, which was republished in Framework (Willemen 1982).

5 Myles followed this up with the publication of a book on the topic: Lynda Myles and Michael Pye, The Movie Brats: How The Film Generation Took Over Hollywood (New York: Holt, Rinehart \& Winston, 1979). 